\title{
Facial Biotype and Mandibular Growth Adaptation in Maxillary Lateral Incisors Agenesis
}

\author{
Biotipo Facial y Adaptación del Crecimiento Mandibular \\ en Agenesia de los Incisivos Laterales Maxilares
}

Teresa Pinho*; Patricia Carvalho**; Victòria Tallón*** \& M $^{\text {a }}$ Cristina Manzanares**

PINHO, T.; CARVALHO P.; TALLÓN, V. \& MANZANARES, M. C. Facial biotype and mandibular growth adaptation in maxillary lateral incisors agenesis. Int. J. Morphol., 32(3):962-967, 2014.

SUMMARY: To verify the eventual relationship between maxillary lateral incisor agenesis (MLIA) and one of the clinically established facial biotypes. The analysis was performed in and between 3 groups: individuals with MLIA, their relatives and a control population defined as "normal" or unaffected. Among these, a comparison between adults and growing individuals was also carried out. The dolicofacial biotype was mainly found in children with bilateral agenesis, while the unilateral agenesis as well as the control population of unaffected children showed mainly a mesofacial pattern. The braquiofacial biotype was prevalent in children without agenesis but (family) related to patients with agenesis. This is the case also for all the adults studied, even if the frequency of the braquiofacial is similar to the one attained by the mesofacial biotype when found in unaffected individuals related with agenesis patients. The notable variability found, evidenced by the high values of the standard deviations calculated for each group, makes difficult to definitely establish a positive correlation between the MLIA and one of the facial biotypes with the present data.

KEY WORDS: Facial biotype; Agenesis; Craniofacial patterns; Orthodontics.

\section{INTRODUCTION}

In a Portuguese population, maxillary lateral incisor agenesis (MLIA) prevalence was estimated as $1.3 \%$, with a slightly higher frequency in females (Pinho et al., 2005). Dental agenesis is related to a growing set of genetic alterations; however, the data about the genes responsible of some forms of dental agenesis are yet sparse and controversial (de Sabòia et al., 2013; Tallón-Walton et al., 2014). In an initial study carried out in 12 Portuguese families with MLIA, no conclusive results relating this phenotype with PAX9 and MSX1 genes were found (Pinho et al., 2010a). However, a posterior familiar aggregation analysis of 62 MLIA probands and 142 first degree relatives proved that the relative risk (RR) of presenting dental agenesis was 15 times superior for a first degree family member of an agenesis patient than for a person non related to an agenesis patient. These results showed that MLIA almost never segregates with other agenesis phenotypes, as well as that significant familiar aggregation is evident in the MLIA patients (Pinho et al., 2010b). Moreover, microdontia seems to be a part of the same phenotype (Pinho et al., 2009; Pinho et al., 2010b), as is the case for other agenesis (Tallón-Walton et al., 2010a) and for agenesis-related phenotypes, such as the Midline Syndrome (Tallón-Walton et al., 2010b).

Direct and indirect clinical signs can led us to suspect a MLIA, such as the persistence of a temporary lateral incisive beyond the time of eruption of the definitive, and/or asymmetrical loss of temporary tooth. In a similar manner, a Class II dental relation or the deviation of the middle line to the same side of a unilateral agenesis can be considered as the evidence of dental compensation acting to diminish the MLIA consequences (Pinho et al., 2009; Pinho et al., 2011).

Despite the lack of a general consensus on whether the changes that may occur during maxillary development are correlated or not with dental agenesis, some authors have described a possible association between these phenotypic traits (Wisth et al., 1974; Woodworth et al., 1985; Pinho et

\footnotetext{
* Instituto Superior de Ciências da Saúde-Norte/CESPU; Instituto de Investigação e Formação Avançada em Ciências e Tecnologias da Saúde (IINFACTS)/

** Unidad de Anatomia y Embriología Humana, Dpt. PiTEx, Barcelona University, Health campus-Bellvitge, L'Hospitalet, Spain.

The present research project has received support from the Instituto de Investigação e Formação Avançada em Ciências e Tecnologias da Saúde (IINFACTS)/CESPU and ACESBELL Research Grant Program (Campus de Bellvitge, Health University of Barcelona campus (HUBc)).
} 
al., 2011). MLIA is indeed associated with an upper maxilla shortening, and also with a negatively conditioned anteriosuperior facial height dimension. Woodworth et al. reported that the decrease in maxillary length in individuals with MLIA is more frequently associated with skeletal Class III. However, other papers reported that dental agenesis of a limited number of teeth has little or no effect on craniofacial structure, since there is a higher prevalence ratio of skeletal Class I in patients with agenesis (Dermaut et al., 1986; Yuksel \& Uçem, 1997; Pinho et al., 2011).

Patients with severe congenital teeth absence have unique dental and skeletal patterns (Ben-Bassat \& Brin, 2009) that have been attributed to a reduced occlusal support (Nodal et al., 1994). Thus, the particular dentofacial development in individuals with severe hypodontia may be due to skeletal and functional compensation rather than being motivated by a different growth pattern (Ogaard \& Krogstad, 1995).

This study aims to evaluate the facial biotype in MLIA in a Portuguese population in order to define an eventual association of these phenotypical traits.

\section{MATERIAL AND METHOD}

Subjects. The 147 individuals were divided in two age groups: 43 in a growth phase (A) and 104 adults (B) (females older than 14 and males older than 18). The sample was divided in three groups: Group 1 -MLIA patients, Group 2 MLIA patients (group 1) family members without MLIA and Group 3 -general population (without agenesis and unrelated to MLIA patients).

Children under nine years, patients submitted to orthodontic treatment and/or maxillo-facial surgery, and individuals with obvious persistence of abnormal pressure habits or sectional cross-bite (skeletal, functional or dental), scissor bite (just one tooth in the lateral segment obeying this condition), history of tooth extraction, other agenesis, other dental anomalies or associated diagnosed syndromes, were excluded of the study.
Approval was obtained by the Ethics Committee of the Medical Dentistry School (University of Porto, Portugal), according with the Portuguese bylaws. Patient or parental written informed consent was obtained in all cases.

Cephalometry methods. The evaluation of the facial biotype was made on a graphical database, by way of the Nemoceph ${ }^{\circledR}$ program (Version 4) and was related to the calculation of five angular measurements that determine the chin position on the space, according to Rickets philosophy (Table I).

1.- Facial axis angle (NaBa-PtGn): infero-posterior angle formed by the basocranean plane and the facial axis;

2. - Facial angle or facial depth (HF-NaPog): angle between the Frankfurt horizontal plane and the facial plane;

3. - Mandibular plane angle (HF-MeAg): angle formed between the mandibular plane and the Frankfurt horizontal plane;

4. - Lower facial height (Ena-Xi-Pm): angle formed by the plane Ena-Xi and Xi-Pm,;

5. - Mandibular arch (Dc-Xi-Pm): complementary angle formed by the axis of the body of the mandible with condylar axis.

Accepted Dahlberg formula (Houston, 1983), Dpe= $\left(\sum \mathrm{D} 2 / 2 \mathrm{~N}\right) 1 / 2$, where $\sum \mathrm{D} 2$ corresponds to the sum of squares of the differences between the first and second measurement and $\mathrm{N}$ means the total number of cases used in the evaluation, was used to calculate the standard intra-investigator error deviation, for angular and linear measurements.

The reliability of the used measures was evaluated by repeating the computerized cephalometry 2 months after, in 30 randomly selected patients ( $20.5 \%$ of the sample). The standard deviation of the error was $0.73^{\circ}-1.43^{\circ}$, for the angular measurements.

Statistical analysis. Cephalometric variables were compared between groups by a univariate ANOVA. The NewmanKeuls post-hoc test for multiple comparisons was used. Significance level was set at 0.05. Statistical analyses were performed using GraphPad Prim 4®.

Table I. Correction factors of the five angles used in the facial biotype (Gregoret, 1997).

\begin{tabular}{lcccccccc}
\hline & \multicolumn{4}{c}{ Female and Male } & \multicolumn{3}{c}{ Male } \\
\hline Age (years) & $\mathbf{9}$ & $\mathbf{1 0}$ & $\mathbf{1 1}$ & $\mathbf{1 2}$ & $\mathbf{1 2}$ & $\mathbf{1 4}$ & $\mathbf{1 5}$ & $\mathbf{1 6}$ \\
Facial axis $\mathbf{(}^{\mathbf{0}}$ ) & 90 & 90 & 90 & 90 & 90 & 90 & 90 & 90 \\
Facial angle $(>\mathbf{0 . 3 / y}$ ear) & 87 & 87.3 & 87.6 & 87.9 & 88.2 & 88.5 & 88.8 & 89.1 \\
Mandibular plane angle (<0.3/year) & 26 & 25.7 & 25.4 & 25.1 & 24.8 & 24.5 & 24.2 & 23.9 \\
Lower facial height & 47 & 47 & 47 & 47 & 47 & 47 & 47 & 47 \\
Mandibular arch $(>\mathbf{0 . 5 / y e a r )}$ & 26 & 26.5 & 27 & 27.5 & 28 & 28.5 & 29 & 29.5 \\
\hline
\end{tabular}


According to Ricketts (1961), the first parameter to determine the facial type is the patient's age. The values thus considered are referred to individuals aged of 9 or more years. Consequently, since the objective of the present study is to evaluate the possible influence of the agenesis of the maxillary lateral incisors on the craniofacial and dental structures, only nine years-old or older subjects, both patients, family members and control group were included (Ricketts; Aasheim \& Ogaard, 1993).

From the five angles submitted to the study, only the ones corresponding to the facial axis and to the anteroinferior facial height do not suffer corrections with age. Thus, the computerized cephalometric study proceeded to automatically correct these parameters (Table I).

After obtaining the angular measurements, the facial biotype was defined as braquifacial, mesofacial or dolicofacial. In the brachiofacial subjects, angles 1, 2 and 5 tend to increase, while angles 3 and 4 tend to diminish; on the contrary, for the dolicocephalic patients, angles 1 , 2 and 5 tend to decrease, and 3 and 4 angles tend to increase; in the mesofacial patients, as expected, the values are nearer the normal.

The Nemoceph ${ }^{\circledR}$, version 4.1 computer program used to the analysis of the cephalometrics (Gregoret, 1997), calculates in an automatic manner in order to establish the facial biotype according with the values obtained for each one of these five angles (Table II).

Table II. Facial type and severity of Biofacial type.

\begin{tabular}{lr}
\hline Facial type and severity & Angle value \\
\hline Dolichofacial severe & $<-1.8$ \\
Dolichofacial medium & -1.7 to -1 \\
Dolichofacial smooth & -0.9 to -0.5 \\
Mesofacial & -0.4 to +0.4 \\
Brachyfacial smooth & +0.5 to +0.9 \\
Brachyfacial medium & +1 to +1.7 \\
Brachyfacial severe & $>+1.8$ \\
\hline
\end{tabular}

\section{RESULTS}

The facial biotypes attributed to the subjects in growth phase (groups A) are shown in Tables III and IV; and to adults (groups B) in Tables V and VI.

Facial Biotype in Individuals in Growth Phase (Group A). Taking into account the minimal and maximal values found, there are huge discrepancies in the attribution of facial biotypes in all the groups, these being less obvious in the unaffected individuals with no family relation with MLIA patients. However, if we consider the median values, a tendency in the individuals affected of bilateral agenesis and family related with other MLIA patients is to present a mesofacial pattern, with a slight prevalence to dolicocephaly. This does not coincide with the findings from all the other groups: with and without unilateral agenesis, with and without family ties to MLIA patients (Table III). Moreover, when the analysis is centered in the three facial biotypes (meso-, brachi- and dolicocephalic) it is visible that the dolicofacial pattern is more prevalent in individuals with bilateral agenesis $(55.5 \%)$ than in those with unilateral agenesis $(12.5 \%)$ or even in the unaffected either if they are related $(38.5 \%)$ or not $(15.45 \%)$ to a MLIA patient. Mesofacial pattern was predominant in individuals affected by unilateral MLIA (75\%) as well as in individuals without either agenesis or family ties to MLIA patients (53.8\%). On the other hand, we found the brachiofacial pattern to be the more prevalent $(46.2 \%)$ in individuals unaffected by MLIA but related to patients affected by MLIA (Table IV).

Facial Biotype in Adult Subjects (Group B). When analyzing the tables corresponding to our adult subjects (Table V), an ample discrepancy is evident with respect to the facial biotypes found in all the groups, similar to the discrepancy observed in the growing individuals, albeit it was less obvious in the subjects without agenesis and not related to agenesis patients. The brachifacial biotype was predominant in all the study groups: 50\% in bilateral MLIA patients, $52.6 \%$ in unilateral MLIA patients; $34.4 \%$ in

Table III. Facial biotype in individuals in growth phase (group A), according to the average values.

\begin{tabular}{lccrc}
\hline & n (\%) & $\begin{array}{c}\text { Variability Minimum/ } \\
\text { Máximum }\end{array}$ & Average \pm SD & Facial Pattern \\
\cline { 2 - 5 } A-1.1 & $9(20.9)$ & $-2 / 2.2$ & $-0.3333 \pm 1.17$ & Mesofacial \\
A-1.2 & $8(18.6)$ & $-1.1 / 1.4$ & $0.175 \pm 0.71$ & Mesofacial \\
A-2 & $13(30.2)$ & $-1.8 / 1.4$ & $0.2308 \pm 1.00$ & Mesofacial \\
A-3 & $13(30.2)$ & $-0.6 / 0.9$ & $0.2385 \pm 0.48$ & Mesofacial \\
\hline
\end{tabular}

A-1.1= Bilateral MLIA; A-1.2= Unilateral MLIA; A-2= MLIA patient's family members and A-3= General population (without agenesis and unrelated to MLIA patients). 
PINHO, T.; CARVALHO P.; TALLÓN, V. \& MANZANARES, M. C. Facial biotype and mandibular growth adaptation in maxillary lateral incisors agenesis. Int. J. Morphol., 32(3):962-967, 2014.

Table IV. Facial biotype in the growing phase, according to the percentage of individuals from each biotype.

\begin{tabular}{|c|c|c|c|c|c|c|c|c|}
\hline & $\begin{array}{c}\text { Dolichofacial } \\
\text { severe }\end{array}$ & $\begin{array}{c}\text { Dolicofacial } \\
\text { medium }\end{array}$ & $\begin{array}{c}\text { Dolicofacial } \\
\text { smooth }\end{array}$ & Mesofacial & $\begin{array}{c}\text { Brachyfacial } \\
\text { smooth }\end{array}$ & $\begin{array}{c}\text { Brachyfacial } \\
\text { medium }\end{array}$ & $\begin{array}{c}\text { Brachyfacial } \\
\text { severe }\end{array}$ & Total \\
\hline Values & $<-1.8$ & -1.7 to -1.0 & -0.9 to -0.5 & -0.4 to +0.4 & 0.5 to 0.9 & 1 to 1.7 & $>1.8$ & \\
\hline A-1.1 & $1(2.32 \%)$ & $1(2.32 \%)$ & $3(7 \%)$ & $3(7 \%)$ & 0 & 0 & $1(2.32 \%)$ & 9 \\
\hline A-1.2 & 0 & $1(2.32 \%)$ & 0 & $6(14 \%)$ & 0 & $1(2.32 \%)$ & 0 & 8 \\
\hline A-2 & $1(2.32 \%)$ & $2(4.6 \%)$ & $2(4.6 \%)$ & $2(4.6 \%)$ & $4(9.3 \%)$ & $2(4.6 \%)$ & 0 & 13 \\
\hline A-3 & 0 & 0 & $2(4.6 \%)$ & $7(16.3 \%)$ & $4(9.3 \%)$ & 0 & 0 & 13 \\
\hline Total & $2(4.64 \%)$ & $4(9.24 \%)$ & $7(16.2 \%)$ & $18(41.9 \%)$ & $8(18.6 \%)$ & $3(6.9 \%)$ & $1(2.32 \%)$ & 43 \\
\hline
\end{tabular}

A-1.1= Bilateral MLIA; A-1.2= Unilateral MLIA; A-2= MLIA patient's family members and A-3= General population (without agenesis and unrelated to MLIA patients).

Table V. Facial biotype in adult phase (group B), according to the average values.

\begin{tabular}{lcccc}
\hline & $\mathbf{n}(\%)$ & $\begin{array}{c}\text { Variability Minimum/ } \\
\text { Maximum }\end{array}$ & Average \pm DS & Facial Biotype \\
\cline { 2 - 5 } B-1.1 & $24(23.1)$ & $-2 / 2.4$ & $0.242 \pm 0.95$ & Mesofacial \\
B-1.2 & $19(18.3)$ & $-1.2 / 2.5$ & $0.531 \pm 0.94$ & Brachyfacial smooth \\
B-2 & $32(30.8)$ & $-3 / 2.2$ & $0.03 \pm 1.02$ & Mesofacial \\
B-3 & $29(27.9)$ & $-0.9 / 2.8$ & $0.85 \pm 1.02$ & Brachifacial smooth \\
\hline
\end{tabular}

B-1.1= Bilateral MLIA; B-1.2= Unilateral MLIA; B-2= MLIA patient's family members and B-3= General population (without agenesis and unrelated to MLIA patients).

Table VI. Facial biotype in adult phase (group B), according to the percentage of individuals from each biotype.

\begin{tabular}{|c|c|c|c|c|c|c|c|c|}
\hline & $\begin{array}{c}\text { Dolichofacial } \\
\text { severe }\end{array}$ & $\begin{array}{c}\text { Dolicofacial } \\
\text { medium }\end{array}$ & $\begin{array}{c}\text { Dolicofacial } \\
\text { smooth }\end{array}$ & Mesofacial & $\begin{array}{c}\text { Brachyfacial } \\
\text { smooth }\end{array}$ & $\begin{array}{c}\text { Brachyfacial } \\
\text { medium }\end{array}$ & $\begin{array}{c}\text { Brachyfacial } \\
\text { severe }\end{array}$ & Total \\
\hline Values & $<-1.8$ & -1.7 to -1.0 & -0.9 to -0.5 & -0.4 to +0.4 & 0.5 to 0.9 & 1 to 1.7 & $>1.8$ & \\
\hline B-1.1 & $1(4.2 \%)$ & $1(4.2 \%)$ & $3(12.5 \%)$ & $7(29.2)$ & $8(33.3 \%)$ & $3(12.5 \%)$ & $1(4.2 \%)$ & 24 \\
\hline B-1.2 & 0 & $1(5.3 \%)$ & 0 & $8(42.1)$ & $6(31.6 \%)$ & $2(10.5 \%)$ & $2(10.5 \%)$ & 19 \\
\hline B-2 & $2(6.3 \%)$ & $2(6.3 \%)$ & $6(18.8 \%)$ & $11(34.4 \%)$ & $7(21.9 \%)$ & $3(9.4)$ & $1(3.1 \%)$ & 32 \\
\hline B-3 & 0 & 0 & $3(10.3 \%)$ & $7(24.1 \%)$ & $7(24.1 \%)$ & $7(24.1 \%)$ & $5(17.2 \%)$ & 29 \\
\hline Total & 3 & 4 & 12 & 33 & 28 & 15 & 9 & 104 \\
\hline
\end{tabular}

B-1.1= Bilateral MLIA; B-1.2= Unilateral MLIA; B-2= MLIA patient's family members and B-3= General population (without agenesis and unrelated to MLIA patients).

unaffected subjects with family members affected by agenesis (a similar value was observed for mesofacial biotype in this group), and a $65.5 \%$ in the unaffected general population. However, contrary to the results in the growing patients, the dolicofacial biotype was not the more prevalent, only a $21 \%$, in the adult patients with bilateral agenesis (Table VI).

As a corollary, the dolicofacial biotype, with an elongated facies, an obtuse mandibular angle and narrow dental arches, was the one more prevalent in children with bilateral agenesia, while the children groups with unilateral agenesis and unaffected showed a more frequent mesofacial biotype, more balanced in their vertical and horizontal facial dimensions. The brachicephalic biotype, characterized by a powerful masticatory musculature and a squared mandible, with large dental arches, is the more frequently observed, both in children without agenesis but with family ties with agenesis patients, and in all the adult groups. The groups constituted by unaffected adults related to agenesis patients, however, presented also a similar prevalence of the mesofacial pattern.

\section{DISCUSSION}

Previous comparisons of the traditional cephalometric analysis did not identify a clear correlation between dental agenesis and variations in the craniofacial morphology (Roald et al., 1982; Yuksel \& Ucem). However, some statistically significant results suggest that these parameters are related (Wisth et al.; Sarnas \& Rune, 1983; Woodworth et al.). Nevertheless, these studies are not concordant: for instance, Nodal et al., compared groups of patients with multiple agenesis, thus they were unable to find statistically significant differences. 
One of the principal aspects of a previous study (Pinho et al., 2011) was to link the dentoalveolar factors inherent to the presence-or lack thereof- and the position of the maxillary incisors with the structural factors influencing the maxilla and cranial basis. A recent study by Araya-Diaz et al. (2013) where multivariate cephalometric data were submitted to a clustering analysis, proved that the mandibular length is the first relevant variable, because of the strong influence of genetic factors (in our case, the MLIA) on its growth behavior, which will define the morphology development of the face. Thus, the functional kinetics causes compensations and adaptations of the mandible in terms of both dimensions and position respect of the rest of the cranial structures all the long of the cranial growth. This is the reason why numerous signs are evident in the agenesis patients, both in terms of craniofacial morphological biotypes, and in terms of types of malocclusion (Proffit et al., 2007).

The definition of the patient's facial biotype is relevant to health professionals since it describes the craniofacial morphology by means of three basic patterns defined by the growth process (Ricketts; Gregoret). When there is a predominance of the frontal bones, growth is defined as horizontal, with the vertical plane less developed in the so-called brachicephalic biotype. The individual is defined as dolicofacial when, instead, the growth predominance is at the vertical plane with a lesser horizontal development. When growth is harmoniously compensated, the individual shows a mesofacial type, equidistant from the two extreme biotypes.

In the population studied, the majority of the children with bilateral MLIA showed a dolicofacial biotype, while the ones with unilateral agenesis and the controls were classed predominantly within the mesofacial biotype. The individuals without agenesis but related to agenesis patients were mainly found to be brachicephalic, which, added to the fact that the majority of the adult patients studied, including those with uni or bilateral agenesis were also defined as brachicephalic, maintain open the question referred to the relative influence of the MLIA on the determination of the facial biotype. Since the present is a transversal study, comparing all the groups and individuals in one moment, only tendencies have been signaled, while an eventual longitudinal study of the children groups can lead us to more definitive conclusions. Moreover, the variability of the results obtained, revealed by the high values of the standard deviations, makes difficult to establish a firm correlation between the agenesis and the facial biotypes, despite the general tendency of the median values to a mesofacial biotype, both in children and in adults.

Our present results agree with our previous study (Pinho et al., 2011), which took into account the cranial basis, a region of particular interest to the orthodontists, because its potential influence on dental occlusion as well as for being part and parcel of the craniofacial structural growth processes, especially of the maxillofacial complex (Goret-Nicaise et al., 1988; Dhem et al., 1989) and the dental development (Christensen et al., 1993; Lanza et al.). Pre-natal growth studies have proven the existence of a close relation between the development of the maxillary incisors and the development of the osseous dentoalveolar complex, and even of the incisive suture (Cantín et al., 2013). Christensen et al. described a connection between the dental development and the osseous components of the basicranium. The relative growth and position of the basicranial skeletal elements have an obvious influence in the determination of the craniofacial biotype. If the initial prenatal maturation of the dental tissues is related to the maturation of the maxillofacial complex, it is reasonable to assume that this relation will still exist in the postnatal period.

ACKNOWLEDGEMENTS. The present research project has received support from the Instituto de Investigação e Formação Avançada em Ciências e Tecnologias da Saúde (IINFACTS), CESPU and ACESBELL Research Grant Program (Campus de Bellvitge, Health University of Barcelona campus (HUBc)).

PINHO, T.; CARVALHO, P.; TALLÓN, V. \& MANZANARES, M. C. Biotipo facial y adaptación del crecimiento mandibular en agenesia de los incisivos laterales maxilares. Int. J. Morphol., 32(3):962-967, 2014.

RESUMEN: El objetivo fue verificar la eventual relación entre la agenesia de los incisivos lLaterales maxilares (AILM) y los biotipos faciales establecidos en clínica. Se realizó un análisis en tres grupos de sujetos: (i) pacientes afectos de AILM, (ii) sus familiares y (iii) una población control no afecta, definida como normal. Entre los grupos también se comparó a los sujetos en periodo de crecimiento con los adultos. El biotipo dolicofacial fue descrito principalmente en niños con agenesias bilaterales, mientras que los pacientes con agenesias unilaterales y la población control presentaban mayoritariamente un patrón mesofacial. El patrón braquifacial fue prevalente en niños no afectos de agenesia pero miembros de la familia de pacientes afectos de agenesia. Lo mismo se observó en todos los pacientes adultos, aunque la prevalencia del biotipo braquifacial resultó similar a la del biotipo mesofacial en pacientes no afectos de agenesia, pero con relación familiar a pacientes afectos. La notable variabilidad en el grupo sometido a estudio, evidente por los elevados valores de DE obtenidos en cada grupo, no permite establecer de manera definitiva una correlación positiva entre la AILM y un biotipo morfológicos facial, al menos con los datos hasta ahora disponibles.

PALABRAS CLAVE: Biotipo facial; Agenesia; Patrón de crecimiento craniofacial; Ortodoncia. 


\section{REFERENCIAS BLIBLIOGRÁFICAS}

Aasheim, B. \& Ogaard, B. Hypodontia in 9-year-old Norwegians related to need of orthodontic treatment. Scand. J. Dent. Res., 101(5):257-60, 1993.

Araya-Díaz, P.; Ruz, G. A. \& Palomino, H. M. Discovering craniofacial patterns using multivariate cephalometric data for treatment decision making in orthodontics. Int. J. Morphol., 31(3):1109-15, 2013.

Ben-Bassat, Y. \& Brin, I. Skeletal and dental patterns in patients with severe congenital absence of teeth. Am. J. Orthod. Dentofacial Orthop., 135(3):349-56, 2009.

Cantin, M.; Olate, S.; Fonsea, C.; Inzunza, O.; Contreras, F. \& Salgado, G. Morphometrical Study of Human Palatine Sutures in Newborns, Infants and Children for Distraction Osteogenesis Treatment Purposes. Int. J. Morphol., 31(3):1130-6, 2013.

Christensen, L. R.; Kjaer, I. \& Graem, N. Comparison of human dental and craniofacial maturation on prenatal profile radiographs. Eur. J. Orthod., 15(2):149-54, 1993.

de Sabóia, T. M.; Küchler, E. C.; Tannure, P. N.; Rey, A. C.; Granjeiro, J. M.; de Castro Costa, M. \& Vieira, A. R. Mesio-Distal and Buccal-Lingual Tooth Dimensions are Part of the Cleft Spectrum: A Pilot for Future Genetic Studies. Cleft Palate Craniofac. J., 50(6):678-83, 2013.

Dermaut, L. R.; Goeffers, K. R. \& De Smit, A. A. Prevalence of tooth agenesis correlated with jaw relationship and dental crowding. Am. J. Orthod. Dentofacial Orthop., 90(3):204-10, 1986.

Dhem, A.; Goret-Nicaise, M.; Dambrain, R.; Nyssen-Behets, C.; Lengelé, B. \& Manzanares, M. C. Skeletal growth and chondroid tissue. Arch. Ital. Anat. Embryol., 94(3):237-41, 1989.

Goret-Nicaise, M.; Manzanares, M. C.; Bulpa, P.; Nolmans, E. \& Dhem, A. Calcified tissues involved in the ontogenesis of the human cranial vault. Anat. Embryol. (Berl.), 178(5):399-406, 1988.

Gregoret, J. Ortodoncia y cirurgia ortognática - diagnóstico y planificación. Barcelona, Espaxs S.A. 1997.

Houston, W. J. The analysis of errors in orthodontic measurements. Am. J. Orthod., 83(5):382-90, 1983.

Lanza, P.; Santos-Pinto, A. \& Bolini, P. D. A. Estudo cefalométrico do crescimento e flexão da base do crânio humana do nascimento aos seis meses de idade. Rev. Dent. Press Ortodon. Ortoped. Facial, 7(2):33-9, 2003.

Nodal, M.; Kjaer, I. \& Solow, B. Craniofacial morphology in patients with multiple congenitally missing permanent teeth. Eur. J. Orthod., 16(2):104-9, 1994

Ogaard, B. \& Krogstad, O. Craniofacial structure and soft tissue profile in patients with severe hypodontia. Am. J. Orthod. Dentofacial Orthop., 108(5):472-7, 1995.

Pinho, T.; Maciel, P.; Lemos, C. \& Sousa, A. Familial aggregation of maxillary lateral incisor agenesis. J. Dent. Res., 89(6):621-5, 2010 b.

Pinho, T.; Maciel, P. \& Pollmann, C. Developmental disturbances associated with agenesis of the permanent maxillary lateral incisor. Br. Dent. J., 207(12):E25, 2009.
Pinho, T.; Pollman, C.; Calheiros-Lobo, M. J.; Sousa, A. \& Lemos, C. Craniofacial repercussions in maxillary lateral incisors agenesis. Int. Orthod., 9(3):274-85, 2011.

Pinho, T.; Silva-Fernandes, A.; Bousbaa, H. \& Maciel, P. Mutational analysis of MSX1 and PAX9 genes in Portuguese families with maxillary lateral incisor agenesis. Eur. J. Orthod., 32(5):582-8, 2010a.

Pinho, T.; Tavares, P.; Maciel, P. \& Pollman, C. Developmental absence of maxillary lateral incisors in the Portuguese population. Eur. J. Orthod., 27(5):443-9, 2005

Proffit, W. R.; Fields, H. W. \& Sarver, D. M. Contemporary orthodontics. 4th ed. St. Louis, Mosby, 2007.

Ricketts, R. M. Cephalometric analysis and synthesis. Angle Orthod., 31(3):141-56, 1961.

Roald, K. L.; Wisth, P. J. \& Boe, O. E. Changes in cranio-facial morphology of individuals with hypodontia between the ages of 9 and 16. Acta Odontol. Scand., 40(2):65-74, 1982.

Sarnäs, K. V. \& Rune, B. The facial profile in advanced hypodontia: a mixed longitudinal study of 141 children. Eur. J. Orthod., 5(2):133-43, 1983.

Tallón-Walton, V.; Manzanares-Céspedes, M. C.; Carvalho-Lobato, P.; Valdivia-Gandur, I.; Arte, S. \& Nieminen, P. Exclusion of PAX9 and MSX1 mutation in six families affected by tooth agenesis. A genetic study and literature review. Med. Oral Patol. Oral Cir. Bucal, 19(3):e24854, 2014.

Tallón-Walton, V.; Nieminen, P.; Arte, S.; Carvalho-Lobato, P.; Ustrell-Torrent, J. M. \& Manzanares-Céspedes, M. C. An epidemiological study of dental agenesis in a primary health area in Spain: estimated prevalence and associated factors. Med. Oral Patol. Oral Cir. Bucal, 15(4):e569-74, 2010a.

Tallón-Walton, V.; Nieminen, P.; Arte, S.; Ustrell-Torrent, J. M.; CarvalhoLobato, P. \& Manzanares-Céspedes, M. C. Oral findings in Midline Syndrome: a case report and literature review. Med. Oral Patol. Oral Cir. Bucal, 15(4):e579-82, $2010 \mathrm{~b}$.

Wisth, P. J.; Thunold, K. \& Böe, O. E. The craniofacial morphology of individuals with hypodontia. Acta Odontol. Scand., 32(4):281-90, 1974.

Woodworth, D. A.; Sinclair, P. M. \& Alexander, R. G. Bilateral congenital absence of maxillary lateral incisors: a craniofacial and dental cast analysis. Am. J. Orthod., 87(4):280-93, 1985.

Yüksel, S. \& Uçem, T. The effect of tooth agenesis on dentofacial structures. Eur. J. Orthod., 19(1):71-8, 1997.

Dirección para Correspondencia:

Prof. Dra. Teresa Pinho

Department of Orthodontics

Instituto Superior de Ciências da Saúde-Norte/CESPU

Instituto de Investigação e Formação Avançada em Ciências

e Tecnologias da Saúde (IINFACTS)

Rua Central de Gandra, 1317

4585-116 Gandra-PRD

PORTUGAL

Email: teresa.pinho@iscsn.cespu.pt 